\title{
Student Worksheet Based on E-Learning Development to Improve Problem-Solving Skills of Class X MAN 3 Yogyakarta Students in 2019/2020
}

\author{
Muh. Al Ihwan ${ }^{1, *} Z^{\prime}$ uhdan Kun Prasetyo ${ }^{2}$ Wahyu Elko Septiyono ${ }^{1}$ \\ ${ }^{1}$ Master of Physics Education, Faculty of Mathematics and Natural Science, Universitas Negeri Yogyakarta, \\ Indonesia \\ ${ }^{2}$ Department of Natural Science Education, Faculty of Mathematics and Natural Science, Universitas Negeri \\ Yogyakarta, Indonesia \\ *Corresponding author. Email: muhal.2019@student.uny.ac.id
}

\begin{abstract}
This paper aims to develop a student worksheet based on e-learning on valid momentum and impulse material to build on the problem-solving abilities of students in MAN 3 Yogyakarta. The method used is Research and Development (R\&D) with a 4-D model (Define, Design, Develop, and Disseminate). The instruments used include validation sheets and tests. Data in the form of feasibility of e-learning madrasah-based student worksheet to improve students' problem-solving abilities. Data collection methods used in this study contain expert validation, observation, pre-test, and post-test. Data analysis using the sign test. The results showed that 1) the development of e-learning based worksheets with momentum and impulse material was feasible in terms of the validation results. This can be seen from the results of expert validation that show the feasibility of e-learning-based worksheets in improving problem-solving abilities is in the very high category and 2) the effectiveness of using elearning-based worksheets, namely those developed based on the data obtained from the pretest and posttest results can improve solving abilities. problem in the implementation class. So that student worksheet developed based on e-learning madrasah is suitable for improving problem solving abilities.
\end{abstract}

Keywords: Student worksheet based on e-learning, Problem-Solving, Momentum and impulse

\section{INTRODUCTION}

Problem-solving ability cannot be separated from the knowledge structure that students have. In the process of problem-solving students need knowledge from previous experiences, both from learning experiences and daily experiences. In-depth conceptual knowledge of the principles of physics is needed in solving problems. [1], so that students must be active in constructing a knowledge/concept of physics learned [2]. Several cognitive processes are needed to learn conceptual knowledge and build knowledge structures [3]. There are eight metacognition factors to identify the dimensions of problem-solving in physics. These eight factors include procedural knowledge, declarative knowledge, planning, conditional knowledge, monitoring, debugging, evaluation, and information management [4].
The process of solving physics problems as a basis for practicing obedient thinking comes from empirical experience. Aspects of thinking obediently and empirically as an indicator of problem-solving abilities. Thinking skill can determine the success of a person's life and most importantly the ability to solve life problems [5]. The students' problem-solving abilities on impulse, momentum, and momentum impulse theorems were still not optimal for indicators of applying strategies and evaluating solutions [6]. Students' understanding of the concept causes these deficiencies, students are not used to facing contextual and conceptual questions [7].

Students are still weak in activating functional understanding in problem solving. In order for students to be more skilled in solving problems, especially in physics learning, several alternatives can 
be made, including familiarizing students with constructivist learning activities so that the concepts that students understand are structured and more indepth. [8] the application of effective problem-solving strategies to improve students' skills in solving problems on momentum and impulse material [9] Students also need to get used to dealing with contextual problems and practice their reasoning skills by applying concepts [10]. So that students do not just apply formulas based on memory, but there are complex thought processes. Students also need to get used to understanding the physical meaning of physics equations so that they are not limited to memory as a mathematical formula.

Student problem-solving abilities can be improved by using student worksheet, because student worksheet will help effective interaction between teachers and students. By using student worksheet students will have more opportunities to be active in learning activities, thus helping the performance of the learning process by the teacher. Student worksheet as a learning tool generally contain a resume of the material and questions [11]. So that this makes students unable to carry out experiments to find new knowledge by themselves so that the learning process is not effective and efficient. student worksheet is a new revolution to contribute students understand their environment and must play an act as in protecting the environment, so that the environment can be used for sustainability [12].

Quality needs to be improved with effort of student worksheet by designing an attractive student worksheet, based on discovery and investigation, so that it involves students directly in the learning process and learning is more students as the hub rather than teacher as the hub. Student worksheet is effective for improving problem-solving abilities [13]. Educators can develop student worksheets directly. In learning as a facilitator, you have to adjust the situations and conditions in the classroom [14]. Student worksheets are useful to help develop concepts, process skills, problem-solving, and critical thinking, guidelines, obtain notes about the material, information about concepts through systematic learning activities [15].

The development of information technology (IT) is very rapid, all aspects of life reach out, one of which is education and training. Especially in the field of education, especially technology and vocational education [16]. Along with the rapid development of information technology, the need for an IT-based teaching and learning concept and mechanism is inevitable. e-learning influences the conventional education is transformed into digital education and systems. E-learning provides new hope as an alternative solution to most educational problems in Indonesia. Functions can be adjusted according to needs, either as a supplement (addition), a complement, or a substitution for learning activities in the classroom during [17]. E-learning is possible to develop a web-based teaching and learning process. The e-learning system using the internet is also known as internet enabled learning. Presentation of webbased e-learning can be more interactive [18].

Student worksheet on based e-learning is something new for students, so they are more interested and enthusiastic in learning [19]. E-learning become an alternative to learning during the pandemic period. Limitations for face-to-face learning require learning to use e-learning media. In this paper, using madrasah e-learning as a new innovation in learning, especially in madrasah schools. So this paper makes an innovative learning device to facilitate the learning process. Where the product is in the form of student worksheets combined with developments in information technology, in this case e-leaning madrasah. student worksheet is no longer in the form of an oriented textbook but by using information technology it becomes more attractive to make it easier to improve problem-solving abilities.

\section{RESEARCH METHOD}

This research is a development research, in which the tools developed are student worksheet based on elearning madrasah. This study uses the Research and Development (R\&D) method with a 4-D model (Define, Design, Develop, and Disseminate) [20]. This study produced an e-learning student worksheet product. Products developed to improve problemsolving abilities.

\subsection{Place and Time of Research}

This research was conducted at MAN 3 Yogyakarta, Indonesia in May 2020. The research was conducted in the second semester of 2019/2020.

\subsection{Research Subject}

The research subjects were students of class $\mathrm{X}$ MAN 3 Yogyakarta, Indonesia. The research subjects at the field trial stage were class X IPA 2, 30 students as the implementation class.

\subsection{Research Procedure}

This research was conducted using a 4-D model (Define, Design, Develop, and Disseminate) which 
includes the stages of defining, planning, developing and distributing. The research stages that have been carried out in this research include the stages of analysis (curriculum analysis and material analysis), design (material preparation design, making student worksheet based on e-learning, and collecting materials needed in developing student worksheet based on e-learning), development, implementation (implementation of e-learning using madrasah elearning), and disseminating product results to students and schools.

\subsection{Instrument and Analysis Technique}

The instruments in this study were Student worksheets and Problem-Solving Ability test instrument. The problem-solving instrument used was in the form of essays on the pre-test and post-test to determine the increase in students' problem-solving abilities before and after using e-learning student worksheets. The analysis technique carried out in the study used several techniques, namely:

\subsubsection{Student Worksheet Product Feasibility Analysis}

Before conducting research in the field, the student worksheet based on e-learning-media is then validated first using the validation sheet that has been made. Analysis of the assessment sheet data using quantitative descriptive analysis with the following steps:

Looking for the average score of product ratings, using the formula:

$\overline{\mathrm{X}}=\frac{\sum \mathrm{x}}{\mathrm{n}}$

$\overline{\mathrm{X}}$ is the average score, $\Sigma \mathrm{x}$ is the number of items scored, and $\mathrm{n}$ is the number of items, The average value of the total score for each aspect obtained is then converted into qualitative data in the form of product feasibility level. The conversion guidelines can be seen in Table 1 [21].

Table 1. Assessment criteria of physics student worksheet based on e-learning

\begin{tabular}{|l|l|}
\hline Interval Score & Category \\
\hline $\mathrm{X} \geq \overline{\mathrm{X}} i+1.8 \mathrm{SB}_{\mathrm{i}}$ & Very Good \\
\hline$\overline{\mathrm{X}} \mathrm{i}+0,6 \mathrm{SB}_{i}<\overline{\mathrm{X}} \leq \overline{\mathrm{X}} \mathrm{i}+1,8 \mathrm{SB}_{i}$ & Good \\
\hline$\overline{\mathrm{X}} \mathrm{i}-0,6 \mathrm{SB}_{\mathrm{i}}<\overline{\mathrm{X}} \leq \overline{\mathrm{X}} i+0,6 \mathrm{SB}_{\mathrm{i}}$ & Good Enough \\
\hline$\overline{\mathrm{X}} \mathrm{i}-1,8 \mathrm{SB}_{\mathrm{i}}<\overline{\mathrm{X}} \leq \overline{\mathrm{X}} \mathrm{i}-0,6 \mathrm{SB}_{\mathrm{i}}$ & Less Good \\
\hline$\overline{\mathrm{X}} \leq \overline{\mathrm{X}} \mathrm{i}-1,8 \mathrm{SB}_{\mathrm{i}}$ & Very Less Good \\
\hline
\end{tabular}

$\bar{X}$ is actual score, $\bar{X} i$ is average ideal score is $\frac{1}{2}$ ( ideal maksimum score + ideal minimum score), and $\mathrm{SB}_{\mathrm{i}}$ is the ideal standard deviation is $\frac{1}{6}$ (ideal maksimum score-ideal minimum score).

\subsubsection{Data analysis}

The achievement of problem-solving abilities is seen from the scores obtained through tests using 2 tests, namely the pretest and posttest which will then be calculated using calculation of the sign test using the SPSS program and N-gain. The form of this research is pre-experimental design with one group pretest-posttest design as shown in Figure 1.

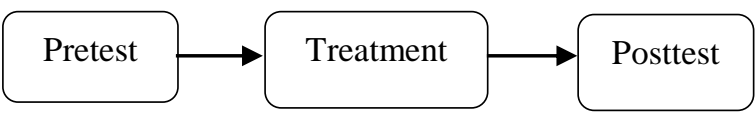

Figure 1 One group pretest-posttest design

Data analysis used quantitative and qualitative analysis techniques. Instrument data for assessing problem-solving abilities in the pretest and posttest produced by the implementation class were analyzed using descriptive statistics and sign test using the SPSS application. The N-gain test was also carried out to see how much improvement each sub-material was discussed. In this study, the $\mathrm{N}$-gain test was used to prevent errors in increasing the score of the students' pre-test and final test data, using the equation:

$\mathrm{N}-$ gain $=\frac{\mathrm{S}_{\text {post }}-\mathrm{S}_{\text {pre }}}{\mathrm{S}_{\text {max }}-\mathrm{S}_{\text {pre }}} \times 100 \%$

The N-gain category is shown in Table 2.

Table 2. N-gain level criteria

\begin{tabular}{|l|l|}
\hline Interval & Criteria \\
\hline $\mathrm{g}>70$ & High \\
\hline $30 \leq \mathrm{g} \leq 70$ & Modarate \\
\hline $\mathrm{g}<30$ & Low \\
\hline
\end{tabular}

\section{RESULTS AND DISCUSSION}

The first step before making a product, the researcher explores a potential problem by making observations at MAN 3 Yogyakarta, Indonesia. Furthermore, the researcher did the planning by thinking about an innovation. Therefore, the researcher made a product in the form of an e-learning madrasah-based student worksheet that was suitable to be used to build on problem-solving abilities.

In accordance with the aspect of the pattern's problem-solving steps, namely analyzing problems, 
preparing solutions, solving problems and evaluating. Solving physics problems using the Minnesota strategy has several obstacles, one of which requires a lot of time to solve the problem, so it is suggested to use the polya problem-solving process [22]. Polya's problem-solving based student worksheet is suitable to improve students' ability to analyze to solve problems [23]. So that overall students are able to apply problem-solving strategies [24]. Furthermore, the student worksheet is prepared by paying attention to problem-solving aspects. Adapted to problem-solving steps. student worksheet that is made contains momentum and impulse material, then student worksheet is divided into 3 according to the material, namely momentum and impulse, restitution. Can be seen in Figure 2.

\section{LKPD 01}

PEMBELAJARAN BERBASIS MASALAH
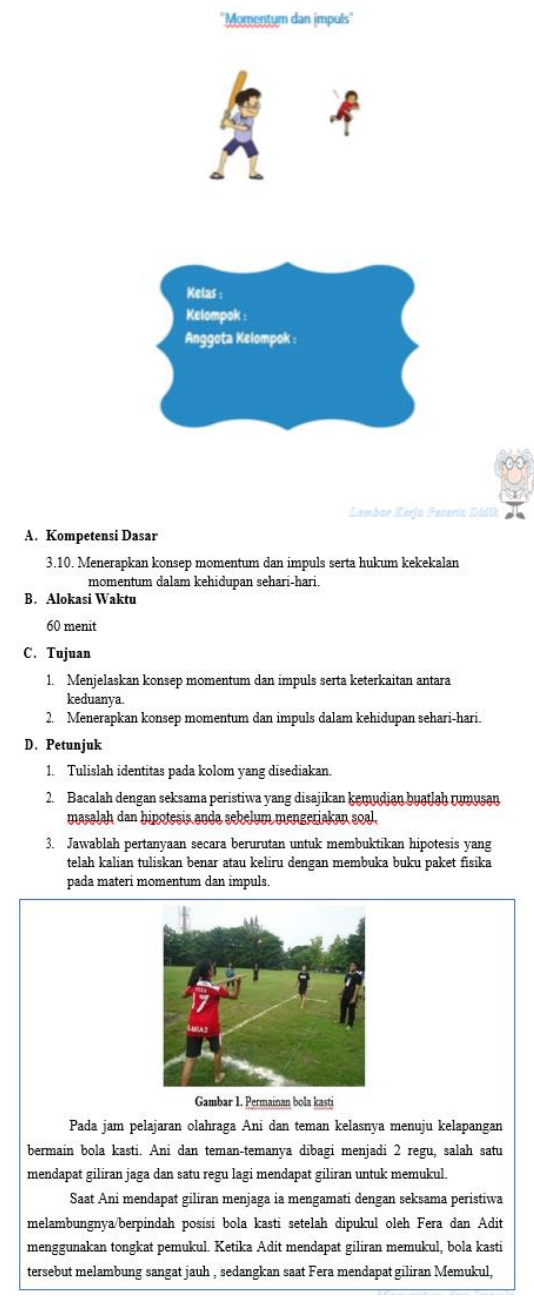

Figure 2 Student worksheet products
Learning tools developed in the form of student worksheet using online learning models. Before conducting research in the field, student worksheet is validated first using the validation sheet that has been made. Analysis of the assessment sheet data using quantitative descriptive analysis. The results of the average total score of each aspect obtained are then converted into qualitative data in the form of product feasibility level. Based on Table 1, a quantitative value conversion guide can be obtained to conclude the feasibility level of the developed student worksheet based on e-learning. If value $\overline{\mathrm{X}} \mathrm{i}$ and $\mathrm{SB}_{\mathrm{i}}$ substituted for the formula in Table 1, the conversion guidelines will be obtained as presented in Table 3 for Intervals 1 to 5 .

Table 3. Convert actual score into qualitative

\begin{tabular}{|l|l|}
\hline Interval Score & Category \\
\hline $\bar{X}>3,4$ & Very Good \\
\hline $2,8<\bar{X} \leq 3,4$ & Good \\
\hline $2,2<\bar{X} \leq 2,8$ & Good Enough \\
\hline $1,6<\bar{X} \leq 2,2$ & Less Good \\
\hline $\bar{X} \leq 1,6$ & Very Less Good \\
\hline
\end{tabular}

Validation of the content and language format aspects of e-learning-based student worksheets was carried out by two validators In this case, the developed student worksheet contains material momentum and impulses that are contextual to everyday life. The analysis results show has been done, the validation data obtained is 3.7. This result shows that student worksheet based on e-learning on momentum and impulse material is in the very good category and meets the validity criteria. Based on the results of the validation, the e-learning student worksheet is feasible as teaching material. The student worksheet developed is contextual to everyday life, so that it is better at improving problem-solving abilities than emphasizing questions and filling in questions [25]. Student as a teaching material is suitable for use when it is in the very good category [26].

The student worksheet that has been developed is applied to the implementation class. During learning in the implementation class, students get full control from the teacher with the help of the WhatsApp application. Through this application, learning syntax is applied starting from initial activity, core, and closing. Preliminary activities begin with the attendance of students. In addition, students also need to ensure that they have installed madrasah e-learning on their respective laptops. After everything is ready, the teacher then directs to read the instructions for 
Table 4. Descriptive statistics of problem-solving ability

\begin{tabular}{|l|l|l|l|l|l|l|} 
& $\mathrm{N}$ & Minimum & Maximum & Sum & Mean & Std.Deviation \\
\hline Pretest & 30 & 7.25 & 9.75 & 248.00 & 8.2667 & .56452 \\
\hline Posttest & 30 & 8.25 & 10.00 & 275.75 & 9.1917 & .44858 \\
\hline Valid N (listwise) & 30 & & & & & \\
\hline
\end{tabular}

Table 5. Frequency of students' problem- solving ability ranks

\begin{tabular}{|l|l|l|l|l|}
\hline & & $\mathrm{N}$ & Mean Rank & \multicolumn{1}{|c|}{ Sum of Rank } \\
\hline Posttest-Pretest & Negative Ranks & 1 (posttest < pretest) & 2.50 & 2.50 \\
\hline & Positive Ranks & 27 (posttest > pretest) & 14.94 & 403.50 \\
\hline & Ties & 2 (posttest = pretest) & & \\
\hline & Total & 30 & & \\
\hline
\end{tabular}

using madrasah e-learning then work on the given student worksheet. The advantages of the student worksheet that are made are that they can be done remotely so that student learning activities can be carried out anytime and anywhere with the help of an internet network. The given student worksheet is based on problem solving that is linked in everyday life, so that students understand it easier the material taught through student worksheet [27].

Student worksheet based on e-learning madrasah carried out the measurement of the problem-solving ability before and after learning. The measurement of students' problem-solving abilities with using instrument test valid and reliable [28] on the pretest and posttest aims to test the effectiveness of the developed student worksheet based on e-learning. Measurement results data were analyzed using descriptive statistics can be seen in Table 4 .

The average pre-test score was 8.26 while the posttest average score was 9.19 which indicates an increase. So, it can be concluded that before and after learning there are differences in problem-solving abilities with the innovations given. Furthermore, to be more-sure the data above will be analysis using the Sign Test. The results of the sign test output can be seen in Table 5.

Based on the data in Table 5, it is found that there is 1 student whose post-test score is smaller than the pre-test. A total of 27 students had post-test scores higher than the pre-test, and 2 students had the same post-test and pre-test scores. Then the statistical test results can be seen in Table 6 .

Table 6. Statistical results of the sign test statistics test wilcoxon signed ranks test

\begin{tabular}{|l|l|}
\hline Z & \multicolumn{1}{|c|}{ Posttest-pretest } \\
\hline Asymp. Sig. (2-tailed) & $\begin{array}{l}-577 \text { (Based on negative } \\
\text { ranks) }\end{array}$ \\
\hline
\end{tabular}

Based on statistical tests using the sign test obtained an alpha of 0.000 . Because $\alpha<0.05, \mathrm{H}_{0}$ is rejected, so that the problem-solving ability increases using student worksheet that has been used in the implementation class. Based on the data obtained, it shows that there are significant differences related to students' problem-solving abilities before and after learning using student worksheet based on e-learning on momentum and impulse material. This difference is indicated by in the mean value of the students' protest and post-test in the implementation class.

The results of improving students' problemsolving abilities can also be seen based on the $\mathrm{N}$-gain value obtained. The $\mathrm{N}$-gain test was used to prevent errors in the interpretation of the increase in score data [29]. Students' problem-solving abilities increase can be seen in Figure 3. 


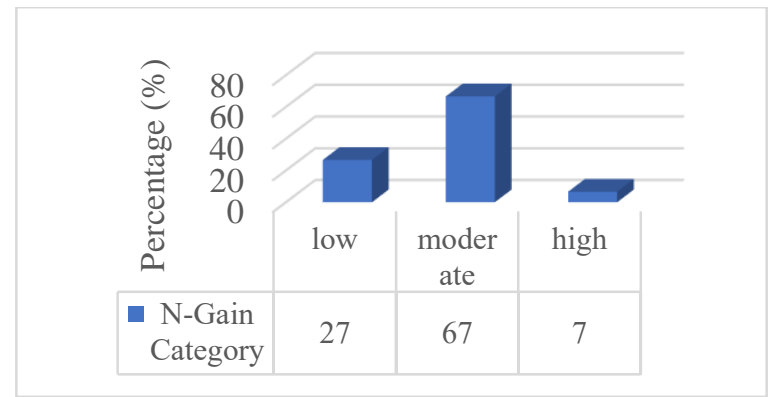

Figure 3 The improvement of problem-solving using $\mathrm{N}$-gain

Based on the picture, the $\mathrm{N}$-gain score is $27 \%$ in the low category, $67 \%$ in the moderate category and $7 \%$ in the high category. In this study, the N-gain test was used to check the increase in problem-solving abilities in terms of the sub material being taught. Based on the results of student responses, this student worksheet provides convenience in learning.

The appearance is quite attractive with an attractive design, so it is not boring when working on it. Questions related to contextual daily life make students understand the problem well. The results provide an increase in students' problem-solving abilities, so that contextual student worksheet can improve problem-solving abilities [30]. There are contrasts in learning outcomes among the use of webbased contextual physics student worksheet and contextual learning. The ability to solve problems in the learning process using the web with contextual physics student worksheet can improve problemsolving skills better than conventional learning [31].

The materials given in student worksheet are momentum and impulse. During the work process students do at home using madrasah e-learning. The teacher provides directions through the given student worksheet. Students answer the questions individually. Then they discussed with other friends. All data students are doing well. Each student shows the results of their answers followed by discussion activities.

\section{CONCLUSION}

Built upon this paper, that it can be concluded development student worksheet based on e-learning Madrasah on momentum and impulse material is feasible in terms of the validation results. This can be seen from the results of expert validation which show that the feasibility of student worksheet based on elearning-in improving problem-solving abilities is in the very high category and the effectiveness of using student worksheet based on e-learning-which is developed based on the data obtained can build on problem-solving abilities in the implementation class. So that the developed student worksheet based on elearning madrasah is suitable for improving problemsolving skills.

\section{REFERENCES}

[1] E. Inch, An Overview of Problem Solving Studies on Physics Education, Journal of Education and Learning 7(4) (2018) 191-200. DOI: https://doi.org/10.5539/jel.v7n4p191

[2] D. Giacalone, Enhancing Student Learning with Case-Based Teaching and Audience Response Systems in An Interdisciplinary Food Science Course, Higher Learning Research Communications 6(3) (2016) 1-19. DOI: http://dx.doi.org/10.18870/hlrc.v6i3.304

[3] Đ. Vukić, S. Martinčić-Ipšić, A. Meštrović, Structural Analysis of Factual, Conceptual, Procedural, and Metacognitive Knowledge in A Multidimensional Knowledge Network, Complexity 1 (2020) 1-17. DOI: https://doi.org/10.1155/2020/9407162

[4] Haeruddin, Z. Prasetyo, Supahar, The Development of A Metacognition Instrument for College Students to Solve Physics, International Journal of Instruction 13(1) 2020 767-782. DOI: https://doi.org/10.29333/iji.2020.13149a

[5] A. Susilo, Pengembangan Model Pembelajaran IPA Berbasis Masalah untuk Meningkatkan Motivasi Belajar dan Kemampuan Berpikir Kritis Siswa SMP, Journal of Primary Education 1(1) (2012) 12-20. DOI: https://doi.org/10.15294/usej.vli1.849

[6] S. Zaenab, M. Makhrus, I. Gunada, Analisis Tingkat Kemampuan Pemecahan Masalah Getaran Harmonis Melalui Model Pembelajaran Perubahan Konseptual, Jurnal Pendidikan Fisika dan Teknologi, 5(1) (2019) 100-109. DOI: http://dx.doi.org/10.29303/jpft.v5i1.813

[7] D. Prihartanti, L. Yuliati, H. Wisodo, Kemampuan Pemecahan Masalah Siswa pada Konsep Impuls, Momentum, dan Teorema Impuls Momentum, Journal of Education 2(8) (2017) 1149-1159. DOI: http://dx.doi.org/10.17977/jptpp.v2i8.9911 
[8] S. Wahyuni, S. Indrawati, W. Suana, Developing Science Process Skills and Problem-Solving Abilities Based on Outdoor Learning in Junior High School, Jurnal Pendidikan IPA Indonesia 6(1) (2017) 165-169. DOI: http://dx.doi.org/10.15294/jpii.v6i1.6849

[9] L. Yuberti, A. Anugrah, A. Seregar, Misbah, Jermsittiparsert, Approaching Problem-Solving Skills of Momentum And Impulse Phenomena Using Context and Problem-Based Learning, European Journal of Educational Research, 8(4) (2019) 1217-1227. DOI: https://doi.org/10.12973/eu-jer.8.4.1217

[10] T. Osterman, Dewey and Mathematical Practice: Revisiting The Distinction between Procedural and Conceptual Knowledge, Journal of Curriculum Studies 51(4) (2019) 457-470. DOI: https://doi.org/10.1080/00220272.2019.1594388

[11] N. Apriyanan, K. Herlina, Abdurrahman, Pengembangan Lembar Kerja Siswa Berbasis Inkuiri Terbimbing untuk Meningkatkan Kemampuan Berpikir Kritis, Jurnal Pendidikan Fisika 7(2) (2019) 92-96. DOI: https://doi.org/10.24252/jpf.v7i2.9332

[12] A. Ekantini, I. Wilujeng, The Development of Science Student Worksheet Based on Education for Environmental Sustainable Development to Enhance Scientific Literacy, Universal Journal of Educational Research 6(6) (2018) 1339-1347. DOI: https://doi.org/10.13189/ujer.2018.060625

[13] I. Tivani, Paidi, Pengembangan LKS Biologi Masalah untuk Meningkatkan Kemampuan Pemecahan Masalah dan Karakter Peduli Lingkungan, Jurnal Inovasi Pendidikan IPA 2(1) (2016) 35-45. DOI: http://dx.doi.org/10.21831/jipi.v2i1.8804

[14] R. Antika, M. Zaini, M. Arsyad, Development of High School Biology Students Worksheets Based on Critical Thinking Skills on The Concept of The Digestive System, Jurnal Biologi Inovasi Pendidikan 2(1) (2020) 36-40. DOI: https://doi.org/10.20527/BINO.V2I1.7949

[15] P. Payudi, C. Ertikanto, N. Fadiawati, Suyatna, The development of Student Worksheet Assisted by Interactive Multimedia of Photoelectric to Build Science Process Skills, International Journal of Science and Applied Science: Conference Series 2(1) (2017) 273-282. DOI: https://doi.org/10.20961/ijsascs.v2i1.16726
[16] G.B. Gebremeskel, A.A. Kebede, Y. Chai, The Paradigm Role of ICT for Behavioral and Educational Psychology: The Case of Developing Countries, International Journal of Information and Education Technology 6(4) (2016) 301-307. DOI: http://dx.doi.org/10.7763/IJIET.2016.V6.704

[17] N. Putri, N. Jampel, I.K. Suartama, Pengembangan E-Learning Berbasis Schoology pada Mata Pelajaran IPA Kelas VIII di SMP Negeri 1 Seririt, Journal Edutech undiksha 2(1) (2014) 1-11. DOI: http://dx.doi.org/10.23887/jeu.v2i1.3796

[18] A. Fardianto, E-learning Dalam Kemajuan Iptek yang Semakin Pesat, Indonesia Journal of Network and Security 8(4) (2019) 16-21. DOI: http://dx.doi.org/10.2311/ijns.v8i4.1598

[19] M. Fuadati, I. Wilujeng, Web-Lembar Kerja Peserta Didik IPA Terintegrasi Potensi Lokal Pabrik Gula Untuk Meningkatkan Rasa Ingin Tahu Peserta Didik, Jurnal Inovasi Pendidikan IPA 5(1) (2019) 98-108. DOI: https://doi.org/10.21831/jipi.v5i1.24543

[20] S. Thiagarajan, D. Semmel, M. Semmel, Instructional Development for Training Teacher of Expectional Children. University Of Mnnesota Minneapolis, 1974.

[21] C. Zarkasyi, C. Partana, Profile of students' selfefficacy in chemistry learning: case study at senior high school, in: Journal of Physics: Conference Series, The 5th International Seminar on Science Education, vol. 1440, IOP Publishing, Bristol, 2020, pp. 1-6. DOI: https://doi.org/10.1088/17426596/1440/1/012011

[22] N. S. Merisa, A. Halim, Mahzum, The effects of Exercise Using Minnesota Strategy Problem Solving Model to Student Learning Outcomes and Critical Thinking Ability, Asian Journal of Science Education 2(1) (2020) 24-32. DOI: http://dx.doi.org/10.24815/ajse.v2i1.14745

[23] L. Nurliawaty, M. Mujasam, I. Yusuf, S. W. Widyaningsih, Lembar Kerja Peserta Didik (Lkpd) Berbasis Problem Solving Polya, Indonesian of Education Journal 6(1) (2017) 7281. DOI: http://dx.doi.org/10.23887/jpiundiksha.v6i1.9183

[24] A. Halim, Yusrizal, Susanna, Tarmizi, An Analysis of Students' Skill in Applying The 
Problem Solving Strategy to The Physics Problem Settlement in Facing Aec as Global Competition, Jurnal Pendidikan IPA Indonesia 5(1) (2016) 1-5. DOI: http://dx.doi.org/10.15294/jpii.v5i1.5782

[25] A. Jayadi, D. Putri, H. Johan, Identifikasi Pembekalan Keterampilan Abad 21 Pada Aspek Keterampilan Pemecahan Masalah Siswa SMA Kota Bengkulu Dalam Mata Pelajaran Fisika, Jurnal Kumparan Fisika 3(1) (2020) 25-32. DOI: https://doi.org/10.33369/jkf.3.1.25-32

[26] M.S. Kahar, I.S. Wekke, M.R. Layn, Development of Problem Solving-Oriented Student Worksheet of Physics Learning in Senior High School, Jurnal Ilmiah Pendidikan Fisika AlBiRuNi 7(2) (2018) 195-206. DOI: https://doi.org/10.24042/jipfalbiruni.v7i2.2802

[27] N.A. Aini, A. Syachruroji, N. Hendracipta, Pengembangan LKPD Berbasis Problem Based Learning pada Mata Pelajaran IPA Materi Gaya, Jurnal Pendidikan Dasar 10(1) (2019) 68-76. DOI:

https://doi.org/10.21009/10.21009/JPD.081

[28] M.A. Ihwan, S.S. Sari, M.S. Ali, Pengembangan Instrumen Tes Hasil Belajar Kognitif Fisika Kelas XI MIA SMA Negeri 5 pinrang, Jurnal Sains dan Pendidikan Fisika 15(2) (2019) 50-57. DOI: https://doi.org/10.35580/jspf.v15i2.11036

[29] J.M. Nissen, R.M. Talbot, A.N. Thompson, B.V Dusen, Comparison of Normalizad Gain And Cohen's D for Analyzing Gains on Concept Inventories, Physical Review Physics Education Research 14(1) (2018) 1-12. DOI: https://doi.org/10.1103/PhysRevPhysEducRes.1 $\underline{4.010115}$

[30] H.D. Putra, T. Herman, U. Sumarno, Development of Student Worksheets to Improve The Ability of Mathematical Problem Posing, International Journal on Emerging Mathematics Education 1(1) (2017) 1-10. DOI: http://dx.doi.org/10.12928/ijeme.v1i1.5507

[31] A. Nurjannah, A. Gani, E. Evendi, M. Syukri, Elisa, Question Webs-Based Learning Science Process Skills and Scientific Questioning Skills of Students, Physics Education Journal 4(1) (2020) 38-48. DOI: https://doi.org/10.21067/mpej.v4i1.4402 